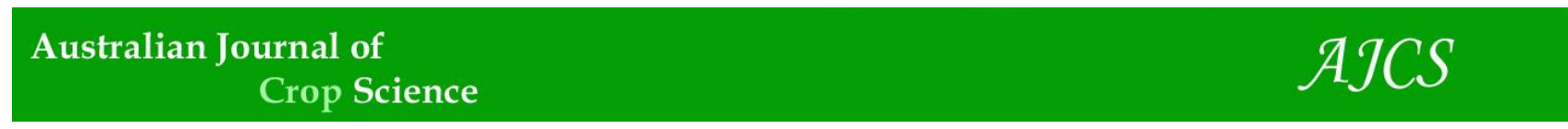

AJCS 10(11):1572-1577 (2016)

ISSN:1835-2707

doi: 10.21475/ajcs.2016.10.11.PNE190

\title{
Economic evaluation of different types of nutritional management in yellow passion fruit vines (Passiflora edulis Sims.).
}

\author{
Rodrigo Takashi Maruki Miyake ${ }^{1 *}+$, Fernanda de Paiva Badiz Furlaneto ${ }^{2}$, Nobuyoshi Narita ${ }^{2}$, \\ William Hiroshi Suekane Takata ${ }^{1}$, José Eduardo Creste ${ }^{1}$
}

\author{
${ }^{1}$ University of Western of São Paulo, Academic Unit of Agricultural, Engineering, Presidente Prudente, CEP \\ 19.067-175, São Paulo, Brazil \\ ${ }^{2}$ Agency Paulista for Agribusiness Tecnology, Scientific Researcher, Presidente Prudente, CEP 19.015-970, São \\ Paulo, Brazil
}

* $\uparrow$ This paper was extracted from the thesis of the first author.

\begin{abstract}
The production costs of passion fruit have increased in recent year mainly due to use of technologies such as different fertilizations, plant density, use of agrochemicals in the protection of plants, production of larger seedlings, among other seeking to increase production. Thus, it is important to know what is the real cost of these techniques to find the financial balance of the production system for increased profitability. The aim of this study was to evaluate the influence and impact of nutritional management on economic terms and production costs of yellow passion fruit. The evaluated parameters were: productivity, commercial production, percentage of commercial fruit, commercial fruit classification, production costs and profitability index of passion fruit vines in the municipality of Presidente Prudente, Brazil. Different N rates $\left(150,300,600\right.$ and $\left.1200 \mathrm{~kg} \mathrm{ha}^{-1}\right), \mathrm{P}_{2} \mathrm{O}_{5}(200,400,800$ and $1600 \mathrm{~kg}$ ha ${ }^{1}$ ) and $\mathrm{K}_{2} \mathrm{O},\left(100,300,500\right.$ and $\left.700 \mathrm{~kg} \mathrm{ha}^{-1}\right)$ were applied. The economic study showed that the production cost increased with the doses of fertilizer. However, this additional economic cost was not reflected in increased productivity per area with the NPK doses. The minimum price for selling passion fruit should be USD 0.26 per kilogram of fruit to obtain economic optimization of entrepreneurial activity. There was positive response in the production for classification of fruit (gauge 2, 3 and 4), commercial production, percentage of commercial fruit and with use to $\mathrm{N}$ and $\mathrm{K}_{2} \mathrm{O}$. Operating profit and profitability index were more satisfactory in the application of $300 \mathrm{~kg}$ of $\mathrm{N}, 200 \mathrm{~kg}$ of $\mathrm{P}_{2} \mathrm{O}_{5}$ and $300 \mathrm{~kg}$ of $\mathrm{K}_{2} \mathrm{O}$ per hectare. In the nutritional management on cost of production showed that there was a percentage difference in operating production cost of $4.52 \%$ between the highest and lowest dose of $\mathrm{N}$. $6.40 \%$ between doses of $\mathrm{P}_{2} \mathrm{O}_{5}$ and $2.52 \%$ between doses of $\mathrm{K}_{2} \mathrm{O}$. The biggest difference in production cost was between the tested and recommended doses of $4.04 \%, 5.81 \%$ and $1.71 \%$ per treatment at different levels of $\mathrm{N}, \mathrm{P}$ and $\mathrm{K}$, respectively. The total operating cost ranged from USD 9,049.76 to 8,4699.97 per hectare.
\end{abstract}

Keywords: Passiflora edulis Sims, fertilization, cost of production, economic indicator, profitability.

Abbreviations: TOC_ Total operating cost; EOC_ effective operational cost; N_ Nitrogen; GR_Gross revenue; PR_Production of activity per unit of arear P; PU_ Unit price of the activity's product; OP_Operating Profit; NR_ Net Revenues; PI_Profitability Index; BP_ Balancing Point.

\section{Introduction}

The passion fruit is a greatly cultivated fruit and appreciated in various regions of Brazil. The passion fruit is marketed predominantly in two ways: fresh fruit for consumption "in natura" and fruit juice (Santos et al., 2011). It is estimated that Brazil currently is the world's largest producer of yellow passion fruit with a production of around 838,000 tons (IBGE, 2016).

The fruit vine is explored predominantly in small orchards with 1.0 to 4.0 hectares, showing the social importance of the production. The long period of harvest, ranging from six to eight months in the Southeast, allows for a monthly income stream, which can contribute to raise the standard of living in rural properties of family farming. Being an activity that usually requires renewal of orchards every 2 years, it promotes the job creation and consequently, labor absorption and fixation in the field (Meletti, 2011; Zaccheo et al., 2012.).
The culture underwent several changes in its production technology, such as cultural conduction and handling in recent years. Among these updates, we can observe planting more productive varieties, reduced plant density and a new nutrient management model to maintain the economic viability of farming, due to the high production cost of rural endeavor (Pires et al.; 2011; Morgado et al., 2015).

Application of new technologies has increased the production costs of passion fruit in recent years, although these techniques have significantly helped producers. However, it is important to note that within these techniques, there are adequate mineral fertilizer plants to improve productivity and thereby increasing the profitability of the production system. Petinari and Tarsinato (2002) aimed to economically analyze the West Indian cherry production. They verified that the costs of planting and formation in two years of the culture has reached US\$ 1269.11/ha. The liquid prescription estimate for West Indian cherry on the fifth year 
was US\$ 4,670.90 corresponding to an index of profitable of $59.23 \%$ by methodology of Martin et al. (1998). The production costs increased by $36 \%$ at third year and net revenues developed in $70 \%$.

The economic analysis of banana production system cv. Grande Naine in the Middle Parapanema region in the state of São Paulo showed that fertilizers account for $22.07 \%$ of the EOC, according to the methodology of costs and profitability of Matsunaga et al. (1976) and Martin et al (1998). In addition, the profitability index (PI) of the largest system was $42.9 \%$ in the third year of production. It increased with increasing the productivity of banana crop (Furlaneto et al, 2007)

In this study, we aimed to evaluate different types of nutritional management with several doses of $\mathrm{N}, \mathrm{P}_{2} \mathrm{O}_{5}$ and $\mathrm{K}_{2} \mathrm{O}$ on the production and classification of fruit to provide specific economic data to the profitability of yellow passion fruit production system in the Western region of São Paulo, Brazil.

\section{Results}

\section{Production and classification of fruits}

There was no significant variation in fruit yield per plant. However, there was differentiation in fruit quality. The percentage and production of commercial fruits were higher using $300 \mathrm{~kg} \mathrm{ha}^{-1}$ of $\mathrm{N}$ and $500 \mathrm{~kg} \mathrm{ha}^{-1} \mathrm{~K}_{2} \mathrm{O}$. There was no significant variation in commercial production at applied doses of $\mathrm{P}_{2} \mathrm{O}_{5}$ (Table 4). Although, there was no difference in passion fruit productivity, phosphorus fertilization caused an increase in the number of total fruits. These fruits were classified as gauge 1 (Table 4), i.e. fruits of no commercial value.

Significant differences were observed in fruit gauge and final product quality after applying various $\mathrm{N}$ and $\mathrm{K}_{2} \mathrm{O}$. The various $\mathrm{P}_{2} \mathrm{O}_{5}$ levels did not affect the fruit parameter. We did not identify variation for fruits of gauge 1, 3 and 5, within doses of $\mathrm{N}$. Yet, the fruits from gauges 2 to 5 were larger with the dose of 150 to $300 \mathrm{~kg} \mathrm{ha}^{-1}$. For different levels of $\mathrm{K}_{2} \mathrm{O}$, we identified only variation in gauges $1\left(100 \mathrm{~kg} \mathrm{ha}^{-1}\right)$ and $3\left(500 \mathrm{~kg} \mathrm{ha}^{-1}\right)$, as shown in Table 5 .

\section{Effect of nutritional management on cost of production}

The economic analysis showed that there was a percentage difference in operating production cost $(4.52 \%)$ between the highest and lowest dose of $\mathrm{N}, 6.40 \%$ between doses of $\mathrm{P}_{2} \mathrm{O}_{5}$ and $2.52 \%$ between doses of $\mathrm{K}_{2} \mathrm{O}$. The biggest difference in production costs were observed between the tested and recommended doses of $4.04 \%, 5.81 \%$ and 1.71 at different levels of N, P and K, per treatment, respectively, (Table 6). The total operating cost ranged from USD 9049.76 to 84699.97 per hectare.

\section{Profitability index according to the gauge and nutritional management}

The total average increase in production of fruits was approximately $3.94,20.51,35.6,32.68$ and $7.26 \%$ for gauges $1,23,4$ and 5 fruits, respectively.

\section{Discussion}

There was no significant variation in fruit yield per plant (Table 4). This result indicates that the dose of $200 \mathrm{~kg} \mathrm{ha}^{-1}$ $\mathrm{P}_{2} \mathrm{O}_{5}$ was sufficient to meet the nutritional demand of passion fruit cultivation. There is also possibility that previous crops fertilization and wastes have supplied the needs of plants.

It is also noteworthy that the minimum dose of $\mathrm{P}_{2} \mathrm{O}_{5}$ in this study caused a high productivity. This does is quite below the maximum dose of $140 \mathrm{~kg}^{\text {ha }}{ }^{-1}$ of $\mathrm{P}$ that has been recommended by Technical Bulletin 100 of the IAC (Raij et al., 1997) to reach yields above $35 \mathrm{tha}^{-1}$ in terms of grams of $\mathrm{P} / \mathrm{plant}$. In this experiment, the minimum dose of triple superphosphate provided $55 \mathrm{~g}$ of P/plant, less than the 210 $\mathrm{g} / \mathrm{plant}$ that already recommended in the Technical Bulletin 100.

Although no evidence was observed in passion fruit productivity, the $\mathrm{P}$ fertilization provided an increase in the number of total fruits. However, these fruits were classified as gauge 1 (Table 4), i.e. fruits of no commercial value.

Almeida et al. (2012) evaluated doses of $\mathrm{N}$ levels (100, 200, 400 and $\left.800 \mathrm{~kg} \mathrm{ha}^{-1}\right)$ and $\mathrm{K}_{2} \mathrm{O}(200,400,800$ and $1600 \mathrm{~kg} \mathrm{ha}$ ${ }^{1}$ ) in yellow passion fruit vines and concluded that nitrogen negatively influenced the number of fruits for consumption "in natura", not interfering with the quality of the fruit. The $\mathrm{P}_{2} \mathrm{O}_{5}$ influenced positively in weight and average fruit diameter and negatively on productivity, particularly with the addition of $400 \mathrm{~kg} \mathrm{~N} \mathrm{ha}^{-1}$.

Rodrigues et al. (2009) studied the production and quality of yellow passion fruit vines in response to fertilization with potassium and found no significant difference between the different doses of $\mathrm{K}_{2} \mathrm{O}$ for most parameters of productivity. However, the average fruit weight increased with the presence of potassium in the fertilizer. Borges et al. (2003) analyzed $\mathrm{N}$ doses $\left(0,100,200,400\right.$ and $800 \mathrm{~kg} \mathrm{ha}^{-1}$ year $^{-1}$ of $\mathrm{N})$ and $\mathrm{K}$ doses $\left(0,200,400,800\right.$ and $1600 \mathrm{~kg} \mathrm{ha}^{-1} \mathrm{year}^{-1}$ of $\mathrm{K}_{2} \mathrm{O}$ ) and found that the increase in NK doses do not affect the productivity of plants and not interfere with the quality of the fruit. However, potassium positively influenced the weight and the average diameter of the fruit.

It is noteworthy that the classification of the yellow passion fruit followed the marketing standards of Ceagesp (2016). The fruits of all gauges ( 1 to 5) of the total area (useful plot and border stripes) of the experiment were collected and classified. The economic analysis showed that there was a percentage difference in operating production cost $(4.71 \%)$ between the highest and lowest dose of $\mathrm{N}, 6.78 \%$ between doses of $\mathrm{P}_{2} \mathrm{O}_{5}$ and $2.57 \%$ between doses of $\mathrm{K}_{2} \mathrm{O}$.

We noticed that the production cost is increased because of the tested doses of fertilizer; however, this additional economic cost was not reached due to increased productivity per area. Instead, we found that variations occurred in commercial quantity of production. Therefore, it is imperative to analyze the profitability of the crop, considering the cost of production in relation to the final sales value of the product generated in each treatment.

Furlaneto et al. (2011) reported the total production cost of $\mathrm{R} \$ 37.751 .67$ per hectare or $\mathrm{R} \$ 1.89$ per kilogram of fruit for passion fruit cultivation in the 2010/2011 crop, in the region of Marília-SP. The profitability indicators proved to be unfavorable for the analyzed productive system, mainly due 
Table 1. Schedule of production of yellow passion fruit in the region of Presidente Prudente, crop 2012/2013.

\begin{tabular}{ll}
\hline Crop 2012 & Activity \\
\hline January-March & Gathering fruit in the field to remove seeds \\
April-August & Sowing seeds \\
September & Field-planting \\
December & Start of flowering \\
Crop 2013 & Activity \\
\hline January-July & Harvest \\
\hline
\end{tabular}

Table 2. Dose of $\mathrm{N}, \mathrm{P}_{2} \mathrm{O}_{5}, \mathrm{~K}_{2} \mathrm{O}\left(\mathrm{kg} \mathrm{ha}^{-1}\right)$ application in experiment of yellow passion fruit, Presidente Prudente, crop 2012/13.

\begin{tabular}{lllll}
\hline Factor & Dose & & & \\
\hline $\mathrm{N}$ & 150 & 300 & 600 & 1200 \\
$\mathrm{P}_{2} \mathrm{O}_{5}$ & 200 & 400 & 800 & 1600 \\
$\mathrm{~K}_{2} \mathrm{O}$ & 100 & 300 & 500 & 700 \\
\hline
\end{tabular}

Table 3. Classification of fruits of yellow passion fruit, according to the gauge system, diameter of fruit (mm) and average price sale (USD kg ${ }^{-1}$ ), Presidente Prudente, crop 2012/13.

\begin{tabular}{lccc}
\hline Class & Gauge & Diameter fruit & Average Price sale \\
\hline $1^{\mathrm{a}}$ & 1 & $\leq 55$ & - \\
$2^{\mathrm{a}}$ & 2 & $\geq 55$ to 65 & 0,47 \\
$3^{\mathrm{a}}$ & 3 & $\geq 65$ to 75 & 0,57 \\
$4^{\mathrm{a}}$ & 4 & $\geq 75$ to 85 & 0,65 \\
Super & 5 & $>85$ & 0,74 \\
Source: Ceagesp-SP, 2016. & &
\end{tabular}

Table 4. Total productivity (TP), total number of fruits (TNF), percentage of commercial fruit (PCF) and commercial fruit yield (CFY) of yellow passion fruit in response of doses of $\mathrm{N}, \mathrm{P}_{2} \mathrm{O}_{5 \mathrm{e}} \mathrm{K}_{2} \mathrm{O}$, Presidente Prudente, crop 2012/13.

\begin{tabular}{|c|c|c|c|c|c|c|}
\hline \multirow[t]{2}{*}{ Factor } & \multirow[t]{2}{*}{ Dose } & \multicolumn{2}{|c|}{ Total productivity } & \multirow{2}{*}{$\begin{array}{l}\text { TNF } \\
\text { uni. }\end{array}$} & \multirow{2}{*}{$\frac{\mathrm{PCF}}{\%}$} & \multirow{2}{*}{$\frac{\mathrm{CFY}}{\text { ton ha }{ }^{-1}}$} \\
\hline & & $\mathrm{kg} \mathrm{plant}^{-1}$ & ton $\mathrm{ha}^{-1}$ & & & \\
\hline \multirow[t]{4}{*}{$\mathrm{N}$} & 150 & 28.74 & 43,54 & 828 & 0.71 & 31.26 \\
\hline & 300 & 29.43 & 44.58 & 816 & 0.78 & 35.09 \\
\hline & 600 & 28.40 & 43.02 & 793 & 0.77 & 33.17 \\
\hline & 1200 & 27.92 & 42.30 & 801 & 0.74 & 31.47 \\
\hline Effect & & NS & NS & NS & $\mathrm{Q}^{* *}$ & $\mathrm{Q}^{*}$ \\
\hline \multirow[t]{4}{*}{$\mathrm{P}_{2} \mathrm{O}_{5}$} & 200 & 27.47 & 41.62 & 755 & 0.77 & 32.05 \\
\hline & 400 & 28.89 & 43.77 & 808 & 0.75 & 32.83 \\
\hline & 800 & 29.16 & 44.17 & 850 & 0.74 & 32.75 \\
\hline & 1600 & 28.96 & 43.88 & 827 & 0.75 & 33.37 \\
\hline Effect & & NS & NS & $\mathrm{Q}^{*}$ & NS & NS \\
\hline \multirow[t]{4}{*}{$\mathrm{K}_{2} \mathrm{O}$} & 100 & 27.99 & 42.40 & 815 & 0.71 & 30.40 \\
\hline & 300 & 29.27 & 44.35 & 851 & 0.74 & 33.09 \\
\hline & 500 & 28.62 & 43.37 & 795 & 0.79 & 34.29 \\
\hline & 700 & 28.60 & 43.33 & 777 & 0.76 & 33.22 \\
\hline Effect & & NS & NS & NS & $\mathrm{L}^{* *}$ & $\mathrm{~L}^{*}$ \\
\hline
\end{tabular}

Table 5. Percentage of classification of fruits of yellow passion fruit in response the doses de $\mathrm{N}, \mathrm{P}_{2} \mathrm{O}_{5}, \mathrm{~K}_{2} \mathrm{O}$ application, Presidente Prudente, crop 2012/13.

\begin{tabular}{|c|c|c|c|c|c|c|}
\hline \multirow[t]{3}{*}{ Fator } & \multirow[t]{3}{*}{ Dose } & \multicolumn{5}{|c|}{ Classification (\%) } \\
\hline & & Gauge 1 & Gauge 2 & Gauge 3 & Gauge 4 & Gauge 5 \\
\hline & & $<55 \mathrm{~mm}$ & $55-65 \mathrm{~m}$ & $65-75 \mathrm{~mm}$ & $75-85 \mathrm{~mm}$ & $>85 \mathrm{~mm}$ \\
\hline \multirow[t]{4}{*}{$\overline{\mathrm{N}}$} & 150 & 4.44 & 23.70 & 34.78 & 31.30 & 5.75 \\
\hline & 300 & 3.13 & 18.06 & 34.17 & 35.16 & 9.45 \\
\hline & 600 & 3.87 & 19.02 & 36.05 & 34.46 & 6.58 \\
\hline & 1200 & 4.29 & 21.27 & 37.37 & 29.79 & 7.20 \\
\hline Effect & & NS & $\mathrm{Q}^{* *}$ & NS & $\mathrm{Q}^{*}$ & NS \\
\hline \multirow[t]{4}{*}{$\overline{\mathrm{P}_{2} \mathrm{O}_{5}}$} & 200 & 3.84 & 19.09 & 34.34 & 34.83 & 7.88 \\
\hline & 400 & 3.98 & 20.98 & 37.05 & 31.96 & 6.01 \\
\hline & 800 & 3.63 & 22.11 & 34.40 & 32.52 & 7.32 \\
\hline & 1600 & 4.29 & 19.88 & 36.59 & 31.40 & 7.26 \\
\hline Effect & & NS & NS & NS & NS & NS \\
\hline \multirow[t]{4}{*}{$\overline{\mathrm{K}_{2} \mathrm{O}}$} & 100 & 5.27 & 23.00 & 34.08 & 29.22 & 8.41 \\
\hline & 300 & 4.10 & 21.29 & 36.55 & 31.77 & 6.27 \\
\hline & 500 & 2.86 & 17.88 & 37.10 & 35.00 & 7.14 \\
\hline & 700 & 3.51 & 19.87 & 34.65 & 34.72 & 7.22 \\
\hline Effect & & $\mathrm{L}^{* *}$ & NS & $\mathrm{Q}^{* *}$ & NS & NS \\
\hline $\mathrm{CV}(\%)$ & & 27.39 & 18.90 & 8.81 & 11.78 & 41.07 \\
\hline
\end{tabular}

SAS regression test- L: linear; Q: quadrátic; NS: non significative:* Significative $(\mathrm{p}<0.05)$; ** significative: $(\mathrm{p}<0.01)$. 
Table 6. Cost of fertilization (CF), total operational cost per hectare (TOC), effective operational cost per treatment (EOC), percentage between the total operational cost per treatment the standard dose and the dose application in yellow passion fruit obtained in experiment with doses of $\mathrm{N}, \mathrm{P}_{2} \mathrm{O}_{5}$ and $\mathrm{K}_{2} \mathrm{O}$ held in Presidente Prudente, crop 2012/13.

\begin{tabular}{|c|c|c|c|c|c|}
\hline Factor & Dose & $\mathrm{CF}$ & TOC & EOC & $\begin{array}{l}\text { Percentage between the TOC of } \\
\text { standard dose and the test dose }\end{array}$ \\
\hline & & USD ha $^{-1}$ & USD ha $^{-1}$ & USD treat $^{-1}$ & $\%$ treat $^{-1}$ \\
\hline \multirow{4}{*}{$\mathrm{N}$} & 150 & $332.97 \mathrm{c}$ & $8495.27 \mathrm{~b}$ & $403.70 \mathrm{bc}$ & $99.33 \mathrm{~b}$ \\
\hline & 300 & $390.50 \mathrm{c}$ & $8552.80 \mathrm{~b}$ & $406.43 \mathrm{~b}$ & $100.00 \mathrm{~b}$ \\
\hline & 600 & $505.55 \mathrm{~b}$ & $8667.85 \mathrm{~b}$ & $411.90 \mathrm{~b}$ & $101.35 \mathrm{~b}$ \\
\hline & 1200 & $735.65 \mathrm{a}$ & $8897.96 \mathrm{a}$ & $422.83 \mathrm{a}$ & $104.04 \mathrm{a}$ \\
\hline \multirow{4}{*}{$\mathrm{P}_{2} \mathrm{O}_{5}$} & 200 & $307.67 \mathrm{c}$ & $8469.97 \mathrm{bc}$ & $402.49 \mathrm{bc}$ & $99.03 \mathrm{~b}$ \\
\hline & 400 & $390.50 \mathrm{c}$ & $8552.80 \mathrm{~b}$ & $406.43 \mathrm{~b}$ & $100.00 \mathrm{~b}$ \\
\hline & 800 & $556.15 \mathrm{~b}$ & $8718.46 \mathrm{~b}$ & $414.30 \mathrm{~b}$ & $101.94 \mathrm{~b}$ \\
\hline & 1600 & $887.46 \mathrm{a}$ & $9049.76 \mathrm{a}$ & $430.04 \mathrm{a}$ & $105.81 \mathrm{a}$ \\
\hline \multirow{4}{*}{$\mathrm{K}_{2} \mathrm{O}$} & 100 & $317.30 \mathrm{bc}$ & $8479.61 \mathrm{~b}$ & $402.95 \mathrm{~b}$ & $99.14 \mathrm{~b}$ \\
\hline & 300 & $390.50 \mathrm{~b}$ & $8552.80 \mathrm{ab}$ & $406.43 \mathrm{~b}$ & $100.00 \mathrm{~b}$ \\
\hline & 500 & $463.69 \mathrm{~b}$ & $8625.99 \mathrm{a}$ & $409.91 \mathrm{ab}$ & $100.86 \mathrm{ab}$ \\
\hline & 700 & $536.88 \mathrm{a}$ & $8699.19 \mathrm{a}$ & $413.38 \mathrm{a}$ & $101.71 \mathrm{a}$ \\
\hline
\end{tabular}

Obs: The means followed by the same letter column non-statistical difference $(\mathrm{P}<0.05)$, according to SAS test $(\mathrm{n}=4)$. The standard dose of $\mathrm{N}, \mathrm{P}_{2} \mathrm{O}_{5}$ and $\mathrm{K}_{2} \mathrm{O}$ recommended by Bulletin 100 to yellow passion fruit corresponding of $140,140 \mathrm{e} 350 \mathrm{~kg} \mathrm{ha}^{-1}$, respectively.

Table 7. Gross revenue (GR Fr) from the sale of fruit, according to the caliber, total gross revenues (Total GR), net revenues (NR), profitability índex (PI) and balancing point (BP) for yellow passion fruit obtained in the experiment with doses de $\mathrm{N}, \mathrm{P}_{2} \mathrm{O}_{5}$ and $\mathrm{K}_{2} \mathrm{O}$ held in Presidente Prudente, Crop 2012/13.

\begin{tabular}{|c|c|c|c|c|c|c|c|c|c|}
\hline Fator & Dose & $\begin{array}{l}\text { GR Fr } \\
\text { Cal. } 2\end{array}$ & GR Fr Cal. 3 & $\begin{array}{l}\text { GRB } \\
\text { Cal.4 }\end{array}$ & $\begin{array}{ll}\text { Fr } & \text { GR Fr } \\
& \text { Cal. } 5\end{array}$ & Total GR & NR & PI & $\mathrm{BP}$ \\
\hline \multicolumn{9}{|c|}{ USD treatment $^{-1} \ldots \ldots \ldots$} & $\mathrm{USD} \mathrm{Kg}^{-1}$ \\
\hline \multirow{4}{*}{$\mathrm{N}$} & 150 & $165.89 \mathrm{a}$ & 294.84 b & $304.29 \mathrm{~b}$ & $63.73 \mathrm{~b}$ & $828.75 c$ & $425.05 \mathrm{~b}$ & $51.29 \mathrm{bc}$ & $0.27 \mathrm{a}$ \\
\hline & 300 & $141.90 \mathrm{~b}$ & $325.16 \mathrm{a}$ & $383.69 \mathrm{a}$ & $117.56 \mathrm{a}$ & $968.32 \mathrm{a}$ & $561.89 \mathrm{a}$ & $58.03 \mathrm{a}$ & $0.24 \mathrm{ab}$ \\
\hline & 600 & $141.27 \mathrm{~b}$ & $324.28 \mathrm{a}$ & $355.48 \mathrm{a}$ & $77.38 \mathrm{~b}$ & $898.41 \mathrm{~b}$ & $486.51 \mathrm{~b}$ & $54.15 \mathrm{~b}$ & $0.26 \mathrm{~b}$ \\
\hline & 1200 & $149.88 \mathrm{~b}$ & $318.93 \mathrm{a}$ & $291.55 \mathrm{~b}$ & $80.33 \mathrm{~b}$ & $840.69 \mathrm{c}$ & $417.86 \mathrm{~b}$ & $49.70 \mathrm{c}$ & $0.28 \mathrm{a}$ \\
\hline \multirow{4}{*}{$\mathrm{P}_{2} \mathrm{O}_{5}$} & 200 & $137.00 \mathrm{c}$ & $298.47 \mathrm{~b}$ & $347.16 \mathrm{a}$ & $89.54 \mathrm{a}$ & $872.17 \mathrm{c}$ & $469.68 \mathrm{a}$ & $53.85 \mathrm{a}$ & $0.26 \mathrm{~b}$ \\
\hline & 400 & $154.23 \mathrm{ab}$ & $329.86 \mathrm{a}$ & $326.31 \mathrm{~b}$ & $69.95 \mathrm{~b}$ & $880.35 \mathrm{~b}$ & $473.92 \mathrm{a}$ & $53.84 \mathrm{a}$ & $0.26 \mathrm{~b}$ \\
\hline & 800 & $162.14 \mathrm{a}$ & $305.52 \mathrm{~b}$ & $331.22 \mathrm{~b}$ & $84.99 \mathrm{a}$ & $883.87 \mathrm{~b}$ & $469.57 \mathrm{a}$ & $53.13 \mathrm{a}$ & $0.27 \mathrm{a}$ \\
\hline & 1600 & $148.54 \mathrm{~b}$ & $331.12 \mathrm{a}$ & $325.87 \mathrm{~b}$ & $85.89 \mathrm{a}$ & $891.42 \mathrm{a}$ & $461.38 \mathrm{~b}$ & $51.76 \mathrm{~b}$ & $0.27 \mathrm{a}$ \\
\hline \multirow{4}{*}{$\mathrm{K}_{2} \mathrm{O}$} & 100 & $156.56 \mathrm{a}$ & $280.96 \mathrm{c}$ & $276.25 \mathrm{~b}$ & $90.64 \mathrm{a}$ & $804.42 \mathrm{c}$ & $401.46 \mathrm{c}$ & $49.91 \mathrm{~b}$ & $0.28 \mathrm{a}$ \\
\hline & 300 & $157.75 \mathrm{a}$ & $327.98 \mathrm{ab}$ & $326.94 \mathrm{a}$ & $73.56 \mathrm{~b}$ & $886.23 \mathrm{~b}$ & $479.80 \mathrm{~b}$ & $54.14 \mathrm{a}$ & $0.26 \mathrm{ab}$ \\
\hline & 500 & $137.29 \mathrm{c}$ & $344.99 \mathrm{a}$ & $373.24 \mathrm{a}$ & $86.80 \mathrm{a}$ & $942.32 \mathrm{a}$ & $532.41 \mathrm{a}$ & $56.50 \mathrm{a}$ & $0.25 \mathrm{~b}$ \\
\hline & 700 & $147.80 \mathrm{~b}$ & $312.16 \mathrm{~b}$ & $358.70 \mathrm{a}$ & $85.03 \mathrm{~b}$ & $903.69 \mathrm{ab}$ & $490.31 \mathrm{ab}$ & $54.26 \mathrm{a}$ & $0.26 \mathrm{ab}$ \\
\hline
\end{tabular}

the high price of inputs and inadequate practices for disease control. The authors also highlighted the need for technical adjustments related to the nutritional and sanitary management of the crop to reduce the total cost of production in order to make the activity profitable.

It is also notable that in the region of Marilia, the passion fruit cultivation has decreased considerably in recent years due to virus attack and other pests. The high cost of production indicated in this study is due to the frequent use of pesticides. According to Furlaneto et al. (2007) the profitability index and the balancing point indicate the most profitable management system.

According to the Yearbook of the Brazilian Agriculture (2013), in the region of Alta Paulista (2012), the dryland passion fruit TOC was R\$27,600.00 per hectare per year, taking into account a productivity of 30 tons per hectare, and a density of 500 plants per hectare. Yet, in the state's Midwest region, the cost of irrigated passion fruit was of $\mathrm{R} \$$ $42,708.00$ per hectare per year, with an average yield of 38 tons per hectare and a density of 1,600 plants per hectare. Therefore, in the municipality of Presidente Prudente, region of Upper Sorocabana, the observed yield was higher than that described in the regions cited above. These values possibly imply the lower rate of incidence of pests and diseases in our experiments. To estimate the profitability of fertilizations, we discarded the production of gauge 1 fruits and we only calculated the sale of 2 to 5 fruit gauges. The sale price of each gauge is described in Table 3. We identified higher gross revenue in the combination of the following fertilization dosage: $300 \mathrm{~kg} \mathrm{~N}, 1600 \mathrm{~kg} \mathrm{P}_{2} \mathrm{O}_{5}$ and $500 \mathrm{~kg} \mathrm{~K}_{2} \mathrm{O}$ $\mathrm{K} \mathrm{ha}^{-1}$. However, a most satisfactory net revenue or operating profit was obtained in the application of $300 \mathrm{~kg} \mathrm{~N}, 400 \mathrm{~kg}$ $\mathrm{P}_{2} \mathrm{O}_{5}$ and $500 \mathrm{~kg} \mathrm{~K}{ }_{2} \mathrm{O}$. The same result occurred in the culture profitability index. For this fertilizer dosage, the minimum sales price of passion fruit needs to be of USD 0.26 ( R \$ 1.00) per kilogram of fruit (Table 7).

In another study, Lima et al. (2009) analyzed the profitability of passion fruit in six Brazilian production centers (Benevides-PA, Araguari-MG, Itapuranga-GO, Region Integrated Development of the Federal District, Bom Jesus of Lapa-BA and Vera Cruz-SP) and found that the passion fruit crop is economically viable in these centers when the productivity is greater than 19 tons per hectare/year. However, due to the sharp increase of the price of inputs and the stable price of fruit kilo in the last 5 years (average of $\mathrm{R} \$$ $1.61 \mathrm{~kg}^{-1}$ ), it becomes necessary to increase productivity per hectare, as well as minimize the cost of production and make the activity economically sustainable. 


\section{Materials and Methods}

\section{Plant materials}

Seed of 'Southern Brazil Afruvec' variety was used in this experiment.

\section{Localization and features of area}

The area selected for the experiment installation is located in the municipality of Presidente Prudente, region of Upper Sorocabana, SP. It is characterized by having $64 \%$ of agricultural production units (UPA) with areas of up to 72 hectares (LUPA, 2015).

The climate is Aw according to the Köppen classification, with tropical rainy summer and dry winter and the coldest month with an average temperature above $18^{\circ} \mathrm{C}$. The driest month has less than $60 \mathrm{~mm}$ rainfall. Annual rainfall is approximately $1250 \mathrm{~mm}$ (CEPAGRI, 2015).

The predominant soil in the region is classified as dystrophic ultisol, characterized by the relatively smooth form of ground, yet wavy, by its not very cohesive nature in the surface and lesser permeability in the subsurface layers. It has high susceptibility to erosion, which requires intensive erosion control practices (IAC, 2015).

The complete production cycle of yellow passion fruit in the region Western of São Paulo is from January to July. The experiment was performed from March 2012 to July 2013 (Table 1).

\section{Production of seedlings}

In the experiment, we cultivated and assessed yellow passionfruit (Passiflora edulis Sims.), 'Southern Brazil Afruvec' variety. The seeds were planted in black plastic bags with holes, with a capacity of 2 liters of substrate. We used the pine bark substrate, coconut fiber, vermiculite, rice husk and nutrients (commercial substrate Bioplant ${ }^{\circledR}$ ) as main raw material. The seedlings had the approximate size of $2 \mathrm{~m}$ of height at the moment of planting in September.

\section{Experimental design}

The spacing between plants was $2 \mathrm{~m}$ and $3 \mathrm{~m}$ between lines $\left(1515\right.$ plants $\left.\mathrm{ha}^{-1}\right)$. The total area of the experiment was equivalent to $3801.6 \mathrm{~m}^{2}$. The treatments were performed in fractionated NPK factorial $4^{3} \times 0.5$ divided into two incomplete blocks. The treatments consisted of variations in doses of $\mathrm{N}, \mathrm{P}_{2} \mathrm{O}_{5}$ and $\mathrm{K}_{2} \mathrm{O}$ (Table 2). Variations used for dose of $\mathrm{N}, \mathrm{P}_{2} \mathrm{O}_{5}$ and $\mathrm{K}_{2} \mathrm{O}$, was based on the dose recommended in the Technical Bulletin 100, the Agronomic Institute of Campinas (Raij et al., 1997) for the passion fruit culture, as well as for the other treatments. The doses of $\mathrm{N}, \mathrm{P}_{2} \mathrm{O}_{5}$ and $\mathrm{K}_{2} \mathrm{O}$ recommended by Raij et al. (1997) correspond to a 140 , 140 to $350 \mathrm{~kg} \mathrm{ha}^{-1}$, respectively, for a planting density of 666 plants per hectare.

\section{Management fertilization}

The sources of chemical fertilizers were ammonium nitrate $(32 \% \mathrm{~N})$, triple superphosphate $\left(42 \% \mathrm{P}_{2} \mathrm{O}_{5}\right)$ and potassium chloride $\left(60 \% \mathrm{~K}_{2} \mathrm{O}\right)$. In all treatments, $100 \%$ of the phosphate fertilizer was applied into the furrow and $100 \%$ of $\mathrm{N}$ and $\mathrm{K}_{2} \mathrm{O}$ were provided in the topdressing. The doses of $\mathrm{N}$ and $\mathrm{K}_{2} \mathrm{O}$ were divided into 7 applications of topdressing over the period from October/2012 to April/2013, and provided in accordance with the development of plants aiming to optimize the use of nutrients.

\section{Evaluated characteristics}

Data were collected from February 2013 to July 2013 at 180 to 360 DAS (days after of planting). To estimate the operating cost of production we used the methodology of the Institute of Agricultural Economics (IAE) described in Martin et al. (1998). The united states dollar (USD) rate price was obtained from the Banco Central do Brasil (PTAX 800) official foreign exchange price measured in fractions and units of the Brazilian national currency, which was R $\$ 3,82$ on 02/11/2015 (Banco Central do Brasil, 2016). The structures considered in the production system were: Costs of fertilization $(\mathrm{CF})=$ price and quantity of fertilizer applied by treatment; Effective operating cost $(\mathrm{EOC})=$ expenditures in labor, operations of machines/equipment and materials consumed during the production process; Total operating costs $(\mathrm{TOC})=$ effective operating cost plus expenses with the depreciation of machinery, direct social charges and rural social security contribution. The activities studied included five steps: soil preparation, planting, crop formation, cultural practices and operations related to harvest. Tillage operations for soil preparation such as disking, leveling, plowing, excavation, pallet placing, liming (furrow), planting (distribution of seedlings and replanting), crop handling (thinning and orientation of plants, spraying to control for pests and diseases, manual weeding, prevention to ant proliferation, manual pollination and harvest were identical in all treatments. In manual operations, we considered: (a) labor: family farming; requiring two people per hectare; (b) useful life of equipment: 10 years; (c) weight of fruits per box: $13 \mathrm{~kg}$; (d) dollar exchange rate: USD 1.15. The prices of materials and labor followed the prevailing values in the city of Presidente Prudente, for the month of November 2015. The hourly cost and depreciation of machinery and implements were based on data available in IEA (2006) and they were adjusted through field research.

The total production corresponded to the sum of the productivity of the plants for each treatment. We also carried out an estimate of production per hectare according to productivity per plant. The economic evaluation also took into consideration: per treatment, the productivity (ton ha ${ }^{-1}$ ), commercial production (ton $\mathrm{ha}^{-1}$ ) and commercial percentage of fruit of each classification (\%). The fruits of 2 to 5 gauge were placed on the table and those of gauge 1 were disposed. Table 3 shows the classification of the fruits according to the caliber and the average selling price.

The profitability indicators adopted were:

(a) Gross Revenue (GR): GR $=\operatorname{Pr} \times \mathrm{Pu}$ where: $\operatorname{Pr}=$ production of activity per unit of area $\left(\mathrm{kg} / \mathrm{ha}^{-1}\right) . \mathrm{Pu}=$ unit price of the activity's product (USD/ha ${ }^{-1}$ );

(b) Operating Profit or Net Revenues (OP or NR): OP = GR TOC where: TOC $=$ total operating cost of production (USD/ha ${ }^{-1}$ );

(c) Profitability Index (PI): PI = (OP/GR) x 100;

(d) Balancing Point $(\mathrm{BP})$ : $\mathrm{BP}=\mathrm{TOC} / \mathrm{Pu}$.

\section{Statistical analysis}

The data were analyzed by the mathematical model : $\mathrm{y}=\mathrm{B} 0$ $+\mathrm{b} 11 \mathrm{~N}+\mathrm{b} 22 \mathrm{P}^{2}+\mathrm{B} 3 \mathrm{~K}+\mathrm{b} 33 \mathrm{~K}^{2}+\mathrm{b} 12 \mathrm{NP}+\mathrm{b} 13 \mathrm{NK}+\mathrm{b} 23 \mathrm{PK}$ submitted to analysis of variance by the statistical program SAS (Statistical Analysis System ) 9.2 ( SAS , 2010), and the variables whose response was significant at doses were 
analyzed by regression test for significance level of $\mathrm{p}<0.05$; $<0.01 \%$.

\section{Conclusion}

The NK fertilization changed the total gross revenues and total net revenues influenced by doses in the commercial percentage, commercial yield and classification of gauge of yellow passion fruit. The dose of $\mathrm{N}, \mathrm{P}_{2} \mathrm{O}_{5}, \mathrm{~K}_{2} \mathrm{O}$, which presented higher economic profitability and net revenues, corresponded to the use of $300 \mathrm{~kg}, 200 \mathrm{~kg}$ and $300 \mathrm{~kg}$ per hectare, respectively. The economic analyses showed that the production cost increased with the tested doses of fertilizer; however, this additional economic cost was not reflected in increased productivity but fruits quality per area. The total operating cost (TOC) ranged from USD 9049.76 to 84699.97 per hectare.

\section{Acknowledgements}

The authors would like to thank the Brazilian Improvement Coordination in Higher Education (CAPES) for the grant to the first author (PROGRAMA PROSUP/CAPES/UNOESTE EDITAL 01/2013).

\section{References}

Almeida RF (2012) Nutrição de maracujazeiro. REV VERDE AGROECO DESENV SUST 7:12-17.

Banco central do Brasil (2015) Conversão de moedas. Available at: http://www4.bcb.gov.br/pec/ conversao/conversao.asp. Acess in 02, November.

Borges AL, Rodrigues MGV, Lima AA, Almeida IE, Caldas RC (2003) Nitrogen and potassium effects on yield and quality of yellow passion fruit, under irrigation. Rev Bras Frutic.29:259-262.

CEPAGRI (2016) Centre of meteorological research and climate applied to agriculture. Climate in municipalities in São Paulo. Available at: http://www.cpa.unicamp.br/ outras-informações/clima-dos-municípios. Acess in 04, January.

CEAGESP (2016) Company warehouse and general warehouses of São Paulo. Brazilian program for the improvement of commercial standards and of packaging of the sour passion fruit. Available at: http://www.ceagesp.com.br. Acess in 12, January.

Furlaneto FPB, Martins NA, Esperancini MST, Vidal AA, Okamoto F (2011) Yellow passion fruit production cost (Passiflora edulis). Rev Bras Frutic. 441-446.

Furlaneto FPB, Martins AN, Camolesi MR, Esperancini MST (2007) Economical analysis of banana cv. Grande Naine production systems in the Middle Paranapanema River region, São Paulo State, Brazil. Cientifica. 2:188-195.

IAC (2016) Campinas agronomic institute. Classification of soils in the state of São Paulo. Available at: http://www.iac.sp.gov.br/solossp/. Acess in 08, January.

IBGE (2016) Brazilian Institute of Geography and Statistics. Municipal Agricultural Production. at: http://www.cnpmf.embrapa.br/planilhas/Maracuja_Brasil 2010.pdf. Acess in 13, May.

IEA (2006) Economy agriculture institute. Yearbook of statistical information on agriculture. 2nd edn, São Paulo, São Paulo.

Lima MM, Azevedo DB, Santos junior S (2009) Comparison of profitability of passion fruit production in six centers in Brazil. Rev Inov Gest Prod. 1: 54-69.
LUPA (2015) Census Survey of Agricultural Production Units. Agricultural Census. 2008. Available at: http://www.agricultura.sp.gov.br/censo-agropecuariopaulista. Acess in 20, December.

Martin NB, Serra R, Oliveira MDM, Ângelo JA, Okawa H (1998) Integrated system of agricultural costs - Custagri. Inf Econ. 28: 7-28.

Matsunaga M, Bemelmans PF, Toledo PEN, Dulley RD, Okawa H, Pedroso IA (1976) Methodology of cost of production used by the agricultural IEA in São Paulo. Economic agriculture institute, 23: 142.

Meletti LMM (2011) Advances in passion fruit crop in Brazil. Rev Bras Frutic. 33: 83-92.

Morgado MAD, Bruckner CH, Rosado LDS, Santos CEM (2015) Development of seedlings of sour passion fruit grafted on wild species of Passiflora. Rev Bras Frutic. 37: 471-479.

Petinari RA, Tarsinato MAA (2002) Economic analysis of the producion of west indian cherry for table in jales-sp: a study of case. Rev Bras Frutic. 24: 411-415.

Pires MM, Gomes AS, Midlej MMBC, São José AR, Rosado PL, Passos HDB (2011) Characterization of passion fruit market. In: Pires, MM, São josé, AR, Conceição, AO, Passion Fruit: technological advances and sustainability, 1rd edn, Ilhéus, Bahia.

Raij BV, Cantarella H, Quaggio JÁ, Furlani AMC (1997) Technical Bulletin. 100 Recommendations for fertilization and liming for the state of São Paulo. Campinas Agronomic Institute, 2nd edn Campinas, São Paulo.

Rodrigues AC, Cavalcante LF, Oliveira AP, Sousa JT, Mesquita FO (2009) Production and mineral composition of yellow passion fruit in soil with "supermagro" biofertilizer and potassium. Rev Bras Afrc Ambient. 13: 117-124.

Santos PC, Lopes LC, Freitas SJ, Sousa LB, Carvalho AJC (2011) Initial growth and nutritional cntent of yellow passion fruit vines submitted to fertilization with different nitrogen sources. Rev Bras Frutic. 33: 722-728.

SAS institute (2010) SAS/STAT 9.2 user's guide. SAS Institute Inc, 2nd edn. Cary, North Carolina.

Year book of Brazilian Agriculture (2013) Passion fruit. FNP, 18th edn, São Paulo, São Paulo.

Zaccheo PVC, Aguiar RS, Stenzel NMC, Sera T, Neves CSVJ (2012) Production and qualitative characteristics of fruits of yellow passion fruit hybrids. Rev Bras Frutic. 34: 1113-1120. 